M. Amzad Hossain, Farida Yeasmin, S.M. Mizanur Rahman, M.S. Rana, Konica J. Fatema

\title{
DETERMINATION OF PHENOL IN THE BANGSAI RIVER WATER OF BANGLADESH BY GAS CHROMATOGRAPHY-MASS SPECTROMETRY
}

A simple, sensitive and rapid gas chromatography-mass spectrometry (GC-MS) method is proposed for the analysis of some environmentally important highly toxic phenols in water. The concentration level of phenol was determined in water at the sampling stations of Savar, Dhaka Export Processing Zone (DEPZ) and Bank Colony of the Bangsai river, Bangladesh. Water samples were collected from different depth of the sampling stations. The phenolic compounds were extracted with dichloromethane, which was further preconcentrated by evaporation. Different concentrations of toxic phenol were obtained in the river water at the various sampling stations. The concentration of highly toxic phenol was found in the range of $0.01-$ $0.998 \mu \mathrm{g} \cdot \mathrm{L}^{-1}$. This method could permit the analysis of water for phenol as well as phenolic derivatives with detection limit as low as $100 \mathrm{ng} \cdot \mathrm{L}^{-1}$.

Keywords: Environmental organic pollutants, Toxic phenolic compounds, Liquid-phase extraction, Pre-concentration, GC-MS.

\section{INTRODUCTION}

Phenolic derivatives are among the most important contaminants present in the environment. These compounds are used in several industrial processes to manufacture chemicals such as pesticides, explosives, drugs and dyes. They also are used in the bleaching process of paper manufacturing. Apart from these sources, phenolic compounds have substantial applications in agriculture as herbicides, insecticides and fungicides. However, phenolic compounds are not only generated by human activity, but they are also formed naturally, e.g., during the decomposition of leaves or wood. As a result of these applications, they are found in soils and sediments and this often leads to wastewater and ground water contamination. Owing to their high toxicity and persistence in the environment, both, the US Environmental Protection Agency (EPA) and the European Union have included some of them in their lists of priority pollutants.

Phenols and substituted phenols are important pollutants in water because of their wide use in many industrial processes, such as the manufacture of plastics, dyes, drugs, antioxidants and pesticides. They are of great environmental concern owing to their high toxicity [1]. For this reason, a number of phenolic compounds are listed in the US EPA list of priority pollutants.

(C) M. AMZAD HOSSAIN, FARIDA YEASMIN, S.M. MIZANUR RAHMAN, M.S. RANA, KONICA J. FATEMA, 2011 
Many analytical techniques have been used for the trace determination of phenols in aquatic environments. High-performance liquid chromatography (HPLC), capillary electrophoresis (CE) and gas chromatography (GC) have been commonly used for the determination of phenolic compounds [2-6]. Although HPLC methods are frequently applied for the analysis of phenols, $\mathrm{GC}$ is often preferred, due to its inherent advantage of high resolution, rapid separation, low cost and easy linkage with sensitive and selective detectors.

Recently, Bagheri et al. [7] investigated determination of phenol and some chlorophenols in water samples by SDME-GC-MS analysis. They derivatized the compounds prior to extraction using acetic anhydride in basic media. A drop of butyl acetate was used for extraction of acetylated phenols from water. In this paper, we describe the new method of extraction and quantification of phenol at different depth of water at various stations of the Bangsai river in Bangladesh.

\section{EXPERIMENTAL}

Chemicals and standard solutions. The standard phenol was obtained from Merck (Darmstadt, Germany). Solvent used for chromatographic separation was dichloromethane (GC grade) and water (GC grade) obtained from Merck (Darmstadt, Germany). The other chemicals those used were analytical or GC grade. Anhydrous sodium sulphate (Merck, Germany) was cleaned by heating at $200^{\circ} \mathrm{C}$ before use. The $\mathrm{pH}$ of water samples was adjusted with $o$-phosphoric acid (Merck). Other reagents were purchased from Merck.

GC-MS analysis. The GC-MS analysis of the crude dichloromethane water extract of the samples was performed using a Varian GC-MS (Model Varian CP 3800, USA) equipped with a VF-5 fused silica capillary column (30m x 0.25 i. d., film thickness $0.25 \mu \mathrm{m}$, Varian, USA). An electron ionization system with the ionization energy of $70 \mathrm{eV}$ was used for the detection of GC-MS. Helium was used as carrier gas with constant flow rate of $1 \mathrm{ml} / \mathrm{min}$. Injector and mass transfer line temperature were set at 250 and $300^{\circ} \mathrm{C}$, respectively. A $20 \%$ split injection mode was selected with a solvent delay time of 4 min with injection volume $1 \mu \mathrm{l}$. The initial column temperature was started at $40^{\circ} \mathrm{C}$ for $1 \mathrm{~min}$, programmed at $8^{\circ} \mathrm{C} \cdot \mathrm{min}^{-1}$ to $200^{\circ} \mathrm{C}$ and heated until $300^{\circ} \mathrm{C}$ at $10^{\circ} \mathrm{C}$. $\mathrm{min}^{-1}$. Injection port was set at $250^{\circ} \mathrm{C}$. Helium was used as carrier gas with a flow-rate of $1.0 \mathrm{ml} \mathrm{min}^{-1}$. Molecular ions were monitored for identification. Mass range: $40-500 \mathrm{~m} / \mathrm{z}$. Identification of the crude dichloromethane extract was based on GC retention time on VF-5 capillary column, computerized matching of mass spectra with standards (Mainlab, Replib and Tutorial data of GC-MS systems). The reference compound, phenol was used as marker. The marker was accurately weighed and dissolved in dichloromethane to produce a series of concentrations. Standard calibration curves were established by 
plotting the peak areas against different concentrations of the reference compound (varying from 0.5 to $10 \mathrm{mg} / \mathrm{ml}$ ). The external standard method was used for quantification of the marker in the Bangsai river water extract.

River water samples. 24 water samples, each of which was collected in a cleaned amber coloured glass bottle from three different stations of the river Bangsai on $20^{\text {th }}$ October, 2009. The stations are Savar, DEPZ and Bank Colony. Sampling stations were at least $1 \mathrm{Km}$ from each other. The locations of the sampling points of the river are shown in Fig. 1. Eight samples were collected from each of the sampling stations and two samples from each sampling points at surface and $30 \mathrm{~cm}$ depth of water. Each sample was collected in 1.1-1 capacity volume, well washed amber coloured glass bottle. At first, the bottle was lowered slowly into the water and its cork was opened by hand, marked accordingly in $\mathrm{cm}$ at the desired depth. When the bottle was filled with water, it is closed and drawn up carefully. Then $100 \mathrm{ml}$ of water was discharged from the glass bottle. At the same time $10 \% \mathrm{CuSO}_{4}$ was added as a stabilizing agent [8] into the water samples, shaken vigorously by hand and closed by the cork.

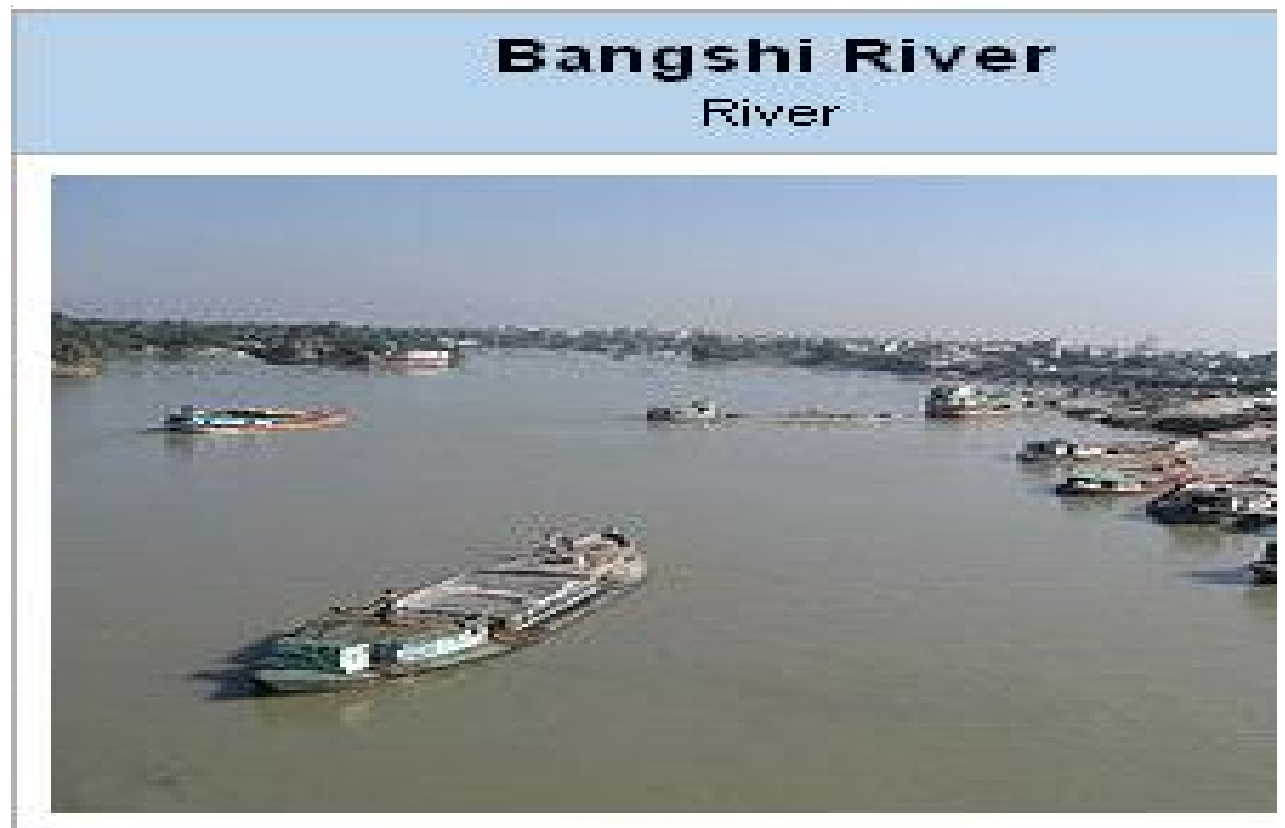

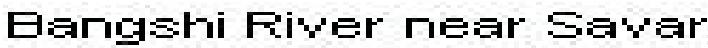

Fig. 1. Map of the Bangsai river showing the locations of the sampling stations and collection points of water samples 
Extraction. The extraction was carried out for $72 \mathrm{hrs}$ after collection of the samples by solvent extraction method [9-11]. The method required two 50-50 capacity conical flask with Teflon stop corks. Each water sample with a volume of $20 \mathrm{ml}$ was poured into the conical flask where $20 \mathrm{ml}$ of dichloromethane was added and the mixture was then shaken vigorously for $1 \mathrm{hr}$ by Lab Tech shaker (Manufacture of Lab. Ind. and Vac. Instrument). After that the water-solvent was transferred to the separatory funnel and then allowed to stand in a rack for 10 min. The aqueous layer was drained into a jar by means of a Teflon stop cork, leaving the dichloromethane layer (extract) in the separatory funnel. The extract was transferred into a volumetric flask. The aqueous layer was extracted again with $10 \mathrm{ml}$ of dichloromethane and the extract was collected and stored. Both extracts were combined into a volumetric flask and kept in a cool atmosphere. All samples (24) were extracted in similar ways.

Removal of residual water from sample extract. In order to remove the residual water from the extract, the extract was treated with anhydrous sodium sulphate. Sodium sulphate $(50 \mathrm{~g})$ was placed in a funnel and slightly watered to make a layer of solid form that does not mix with the extract. The extract was then passed through the funnel and collected in a precleaned volumetric flask. The treated water was restored. The operation was done quickly to avoid possible losses of any volatiles compounds in the extract. A column $(60 \mathrm{~cm}$ long $x 1 \mathrm{~cm}$ i.d.) was used for this operation as well. Fifteen centimeters of the column were packed slowly with silica gel/solid silver nitrate mixture. Before we packed the column, the silica gel was activated at $120^{\circ} \mathrm{C}$ for $10 \mathrm{hr}$ and deactivated with $3 \%$ distilled water by weight. The $10 \mathrm{ml}$ of dichloromethane was introduced into the column to rinse the gel; here $5 \mathrm{ml}$ of dichloromethane was discarded and the remaining $5 \mathrm{ml}$ was retained in the column. Under this condition, the sample extract was passed slowly and carefully through the column. Finally the extract was collected in a suitable container for analysis. All the samples were treated in the same ways.

Preconcentration and analysis of the extract. The extracts were reduced to a volume of $2 \mathrm{ml}$ by evaporation using Kuderna-Danish techniques. By the techniques, dichloromethane was slowly evaporated; a similar evaporation procedure was reported earlier [9-11]. Special attention was given to avoid extra evaporation and the volume of extract $(30 \mathrm{ml})$ was reduced to $2 \mathrm{ml}$ solution. The concentrated solution was preserved in a refrigerator for further analysis. The preconcentrated solutions were injected into the GC-MS instrument and different peaks of phenolic derivatives were obtained in the chromatogram. The phenol was identified and quantified by comparing its retention time and peak area with that of known concentration of standard solution which was also injected into the GC-MS system under the same conditions. The concentration of phenolic derivatives was calculated by using the equation 


$$
\begin{gathered}
\text { conc. of 2,3-dimethyl phenol }= \\
\left.\left(\mathrm{A}_{\mathrm{s}} / \mathrm{A}_{\mathrm{std}}\right) \times\left(\mathrm{I}_{\mathrm{std}} / \mathrm{I}_{\mathrm{s}}\right) \times\left(\mathrm{C}_{\mathrm{std}}\right) \times 2 \text { (conc. factor }\right) \times 1000 \mathrm{ppb},
\end{gathered}
$$

here $\mathrm{A}_{\mathrm{s}}$ and $\mathrm{A}_{\text {std }}$ represent the peak area of component of sample and standard solutions, $\mathrm{I}_{\mathrm{s}}$ and $\mathrm{I}_{\text {std }}$ indicate the injected volume of sample and standards and $\mathrm{C}_{\text {std }}$ is the concentration of standard solution.

\section{RESULTS AND DISCUSSION}

Phenols, and its derivatives, are toxic and potentially carcinogenic, and they can affect the taste and odour of drinking water with concentrations as low as a few $\mu \mathrm{g} / \mathrm{L}$. As a consequence, both the US Environmental Protection Agency (EPA) and the European Union (EU) have included some phenols, mainly chlorophenols and nitrophenols, in their lists of priority pollutants $[8,9]$. EU Directive $2455 / 2001 / \mathrm{EC}$ sets a maximum concentration of $0.5 \mu \mathrm{g} / \mathrm{L}$ in water and their individual concentration should not exceed $0.1 \mu \mathrm{g} / \mathrm{L}$.

The concentrated water samples and standard solutions were introduced into the GC-MS system. Initially no separation of phenolic derivatives was observed when the GC-MS was operated without the control of column and oven temperature. For separation of the phenolic derivatives of the complex mixtures, it was decided to use the column temperature programming resulting in a good separation of individual components present in the river water. The optimum conditions for the separation of phenolic derivatives were: injector temperature $250^{\circ} \mathrm{C}$, initial column temperature was started at $40^{\circ} \mathrm{C}$ for $1 \mathrm{~min}$, programmed at $8^{\circ} \mathrm{C} \cdot \mathrm{min}^{-1}$ to $200^{\circ} \mathrm{C}$ and heated until $300^{\circ} \mathrm{C}$ at $10^{\circ} \mathrm{C} \cdot \mathrm{min}^{-1}$. Helium gas was with flow rate $1 \mathrm{ml} \cdot \mathrm{min}^{-1}$.

Measurement of phenol in the Bangsai river water samples. The quantitative determination of our aim target phenol was done by external calibration curve method. The calibration curve already prepared with known concentration of phenol is detailed below (Fig. 2). Standard curves for phenol generated by plotting the area of four spots vs. the concentration, gave high correlation coefficients. Linear responses were achieved for phenol in the concentration range for water samples. Over this concentration range, the linear regression analysis of peak areas $(\mathrm{y})$ in function of concentration $(\mathrm{x})$, calculated by least square method, leads to the following equations: $y=+1.9415^{\mathrm{e}+003 \mathrm{x}}+$ $1.3531^{\mathrm{e}+004}\left(\mathrm{r}^{2}=0.99963\right)$ for phenol. 


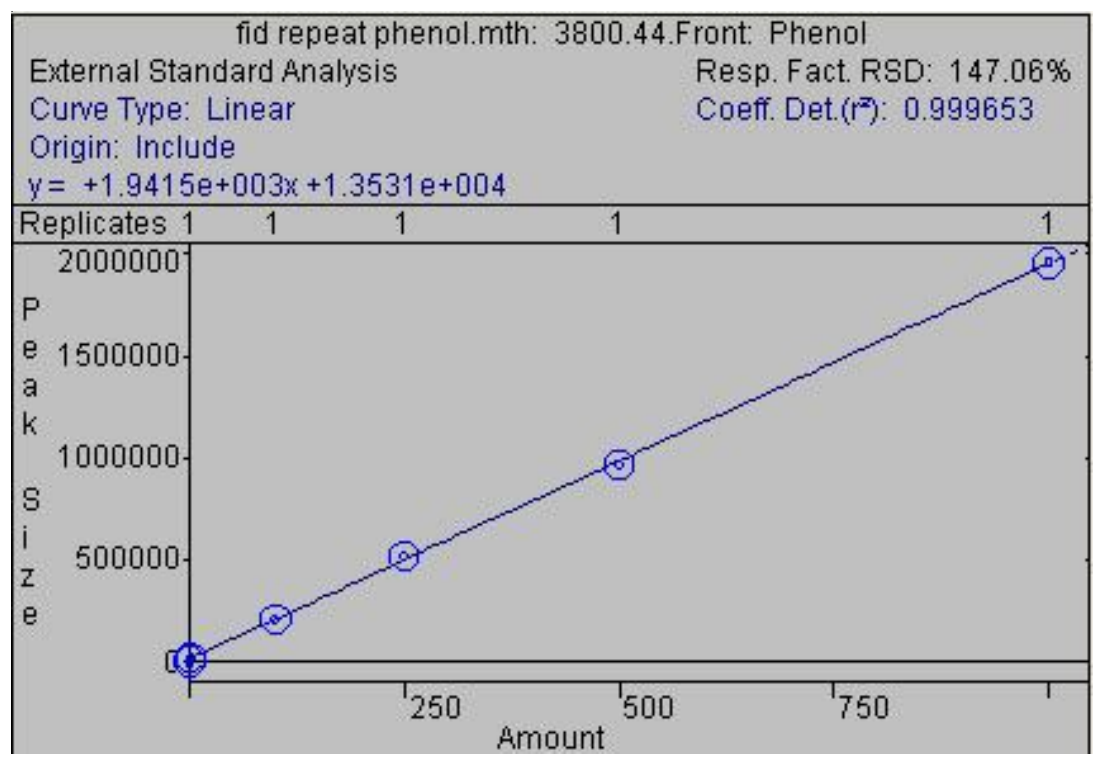

Fig. 2. Standard Calibration Curve of phenol

In order to determine the concentration of phenol on surface and $30 \mathrm{~cm}$ deep water at Savar, DEPZ and Bank Colony stations of the Bangsai river, the preconcentrated were injected into the GC-MS instrument. A comparison of mass spectra for the standard solutions of phenol with the sample solutions, collected from surface water and sample solutions collected from $30 \mathrm{~cm}$ deep water at DEPZ station, is shown in Fig. 3.

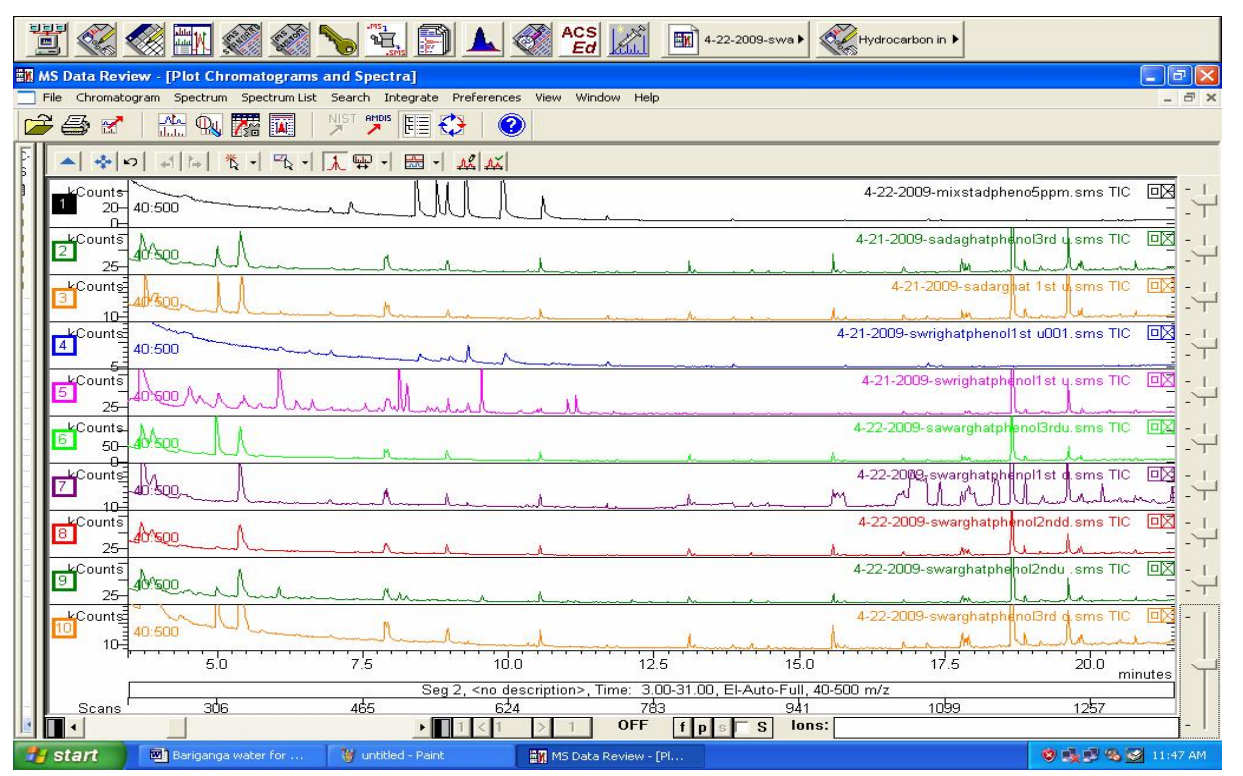

Fig. 3. Comparison of the chromatograms of retention time of standard and water sample extracts, collected from different sampling stations 
This shows an excellent similarity of the retention time (9.214 for standard of phenol) of the separated peak of phenol between standard and sample solutions. But other phenolic derivatives were not found. This is probably due to the presence of very low concentrations in water samples, which is well below the detection limit of GC-MS or may not be present in water samples at the selected locations. Very similar types of chromatograms, not shown in figure, were obtained for surface and $30 \mathrm{~cm}$ deep water samples collected from the other stations, Savar and Bank Colony.

Dhaka is a mega city and it is situated on the bank of Bangsai and Buriganga. About 180 million people live in this mega city. There is a lot of small and big industries such as dyeing, painting etc. linked to the river. May be the industrialist are using phenolic derivatives as a raw material in their industry to produce the finish products. After that they are discharging their effluent directly into the Bangsai river. For that, the high concentration of phenol obtained only from the samples collected from surface and $30 \mathrm{~cm}$ deep water at Savar, DEPZ and Bank colony stations at the eastern parts of the Bangsai river. But the middle sampling points at Savar, DEPZ and Bank colony did not show phenol. This is probably due to the presence of very low concentrations in water samples because it is diluted or may not be present in water samples at the selected locations. The absence or lower concentration of other derivatives of phenols is probably due to their volatility, dissolution, biological degradation, photo oxidation and rapid photolysis [12]. It can also be seen that the concentrations of phenol in surface water are greater than that of those $30 \mathrm{~cm}$ deep. The probable reason is that the higher concentration of phenol arises from the discharge of effluent from the industry. The concentration of phenol for surface and $30 \mathrm{~cm}$ deep water collected from the various stations of the Bangsai river is presented in Table.

Concentration of phenol in surface and $30 \mathrm{~cm}$ deep water at different locations of Bangsai river

\begin{tabular}{|c|c|c|c|c|c|c|c|c|c|}
\hline \multicolumn{9}{|c|}{ Concentration of phenol, ppm } \\
\hline phenol & \multicolumn{3}{|c|}{ Savar } & \multicolumn{3}{c|}{ DEPZ } & \multicolumn{3}{c|}{ Bank colony } \\
\hline & $\begin{array}{c}\text { Eastern } \\
\text { side }\end{array}$ & Middle & $\begin{array}{c}\text { Western } \\
\text { side }\end{array}$ & $\begin{array}{c}\text { Eastern } \\
\text { side }\end{array}$ & Middle & $\begin{array}{c}\text { Western } \\
\text { side }\end{array}$ & $\begin{array}{c}\text { Eastern } \\
\text { side }\end{array}$ & Middle & $\begin{array}{c}\text { Western } \\
\text { side }\end{array}$ \\
\hline Surface & 0.154 & nd & 0.05 & 0.998 & nd & 0.283 & 0.318 & nd & 0.130 \\
\hline $\begin{array}{l}30 \mathrm{~cm} \\
\text { depth }\end{array}$ & 0.085 & nd & 0.01 & 0.529 & nd & 0.176 & 0.192 & nd & 0.102 \\
\hline
\end{tabular}

*nd $=$ not detectable.

Table summarize that the concentration of phenol is different at different sampling stations. The concentration at Sowarighat is relatively higher than the other two sampling stations. The highest concentration for toxic phenol was 
found $0.998 \mathrm{ppm}$ in surface water at the eastern side of DEPZ and the lowest value was recorded as $0.01 \mathrm{ppm}$ in $30 \mathrm{~cm}$ deep water at the western side of Savar sampling station. On the other hand, almost similar trend of results were obtained from the sampling station at Savar, DEPZ and Bank Colony.

\section{CONCLUSIONS}

Phenolic compounds are important priority pollutants in most countries in the world, and many related analytical techniques have been developed for detection of phenols. Present work has been done by our previously established method for phenols determination based on without any derivative process. In conclusion, the concentration of toxic phenol in water samples at Savar, DEPZ and Bank Colony stations of the Bangsai river were determined. Samples were collected from surface and $30 \mathrm{~cm}$ depth of water from each of the sampling stations. The collected samples were extracted, preconcentrated and analyzed by GC-MS. The highest and lowest concentrations were obtained in the river water samples at DEPZ station from eastern side surface and at Savar station from western side $30 \mathrm{~cm}$ depth. Almost similar pattern results were obtained from other station. The experimental results demonstrated that this GC-MS method had offered excellent recoveries and could be employed for environmental sample analysis. In view of the rapidity, sensitivity, simplicity, environment-friendly nature and so on, the proposed method will be an excellent alternative detection technology for phenol analysis, and will be widely employed in environmental and other related fields.

\section{ACKNOWLEDGEMENT}

We are grateful to Dr. S. M. Salehuddin, Chief Scientific Officer, Chemistry Division, Atomic Energy Centre, Ramna, Dhaka for his continuous encourage and logistic support during the work. We also thank to Mr. Zahidul Islam and Mr. Ayub Ali for their help to collection and preparation of the water samples.

Резюме. Предложен простой и экспрессный метод газовой хроматографии и масс-спектроскопии (ГХ - МС) для анализа некоторых высокотоксических фенолов в воде, имеющих большое значение в окружающей среде. Уровень концентрации фенола определяли в воде на станциях отбора проб в Саваре, в зоне обработки экспорта в Даке (ЗОЭВ), а также Банковской колонии на реке Бенгази (Бангладеш). Образцы воды отбирали на разных глубинах на станциях отбора проб. Фенольные соединения выделяли с помощью дихлорометана, который в дальнейшем предварительно концентрировали путем выпаривания. Концентрация фенола была получена в диапазоне $0.01-0.998 \mathrm{mg} \cdot \mathrm{L}^{-1}$. Этот метод дает возмож- 
ность проводить анализ воды на содержание фенола, а также фенольных производных с пределом обнаружения $100 \mathrm{ng} \cdot \mathrm{L}^{-1}$.

Резюме. Запропоновано простой і експресний метод газової хроматографії та мас-спектроскопії (ГХ - МС) для аналізу деяких високотоксичних фенолів у воді, які мають велике значення в навколишньому середовищі. Рівень концентрації фенолу визначався у воді на станціях відбору проб у Саварен, в зоні обробки експорту в Даке (ЗОЕВ), а також Банківської колонії на річці Бенгазі, Бангладеш. Зразки води відбирали на різних глибинах на станціях відбору проб. Фенольні сполуки виділялися за допомогою діхлорометана, який надалі попередньо концентрували шляхом випарювання. Концентрація фенолу була отримана в діапазоні $0.01-0.998 \mathrm{mg} \cdot \mathrm{L}^{-1}$ Цей метод дає можливість проводити аналіз води на вміст фенолу, а також фенольних похідних з межею виявлення $100 \mathrm{ng} \cdot \mathrm{L}^{-1}$.

1. D. Mart'inez, E. Pocurull, R.M. Marcte, M. Calull //J. Chromatogr. A 734 (1996)367.

2. D. Puig, D. Barcelo//Trends Anal. Chem.15 (1996) 362.

3. I. Rodr'iguez, M.P. Llomart, R. Cela //J. Chromatogr. A 885 (2000) 291.

4. E. Pocurull, R.M. Marcte, F. Borrull //J. Chromatogr. A 738 (1996) 1.

5. $\quad$ L. Fang, $X . X u$ // Int. J. Environ. Anal. Chem. 77 (2000) 29.

6. D. de Almeida Azevedo, S. Lacorte, T. Vinhas, P. Viana, D. Barcelo //J. Chromatogr. A 879 (2000) 13.

7. H. Bagheri, A. Saber, S.R. Mousavi //J. Chromatogr. A 1046 (2004).

8. M. A. Hossain, S. M. Salehuddin, Zainul Abedin //Nuclear Science Applications, 8(1/2), (1999) 95 - 97.

9. S. M. Salehuddin, M. A. Motalleb, A. H. Khan//J. Bang. Acad. Sci. 16 (1992) 69.

10. S. M. Salehuddin, A. H. Khan, S. A. Tarafdar//J. Bang. Acad. Sci. 18 (1994) 117.

11. S. M. Salehuddin, A. H. Khan, M. M. M. Rahman // J. Bang. Acad. Sci. 19 (1995) 229.

12. B. J. Readman, I. Tolosa, S. Flower // Marine Pollut. Bull. 32 (1996) 231.

Chemistry Division, Atomic Energy Centre, Ramna, Dhaka;

Department of Chemistry, University of Dhaka,

Dhaka, Bangladesh

Received 15.01.2010 